\title{
Persuasive Nature of Image Schematic Devices in Advertising: Their Use for Introducing Sexisms
}

\author{
María Sol Velasco Sacristán and \\ María Enriqueta Cortés de los Ríos \\ University of Valladolid / University of Almería \\ marisol@tita.emp.uva.es / mecortes@ual.es
}

\begin{abstract}
This paper explores how persuasive is the exploitation of image-schematic devices in advertising, more specifically how they are used for introducing sexism. Using a combined axiological-relevance-theoretic approach we have analysed ten advertisements selected from an online corpus, 'The Advertising is Good for You' blog, and its section on 'Sexist Advertising'. Our analyses have proved that image schematic devices are used to introduce sexism in the advertisements under analysis, mostly the image schemas of space, force, multiplicity and attribute, and mostly by means of covert and weakly overt forms of communication. These image schematic devices seem to be not merely representative of universal experience, but crucially tied to specific socio-cultural cognition, as also suggested by Sinha (2002), Kimmel (2005) and Zlatev (2005), and special cognitive effort and effects are involved with understanding them. Yet, although they seem to contradict a formal application of the Principle of Relevance, as they involve additional processing effort, this is often offset by the extra effects like the pleasure in processing the ad and 'getting' the right meaning and value(s). This pleasurable experience is one important way in which advertisements are persuasive (MeyersLevy and Malaviya, 1999).
\end{abstract}

\section{Introduction}

According to Cognitive Semantics much of our knowledge is not static, propositional and sententional, but is grounded in and structured by various patterns of our perceptual interactions, bodily actions, and manipulations of objects (Johnson, 1987, 1993; Lakoff, 1987; Talmy, 1988). These patterns are experiential gestalts, called image schemas (cf. Gibbs and 
Colston, 2006: 239). One of the most important things about image schemas is that they underlie all aspects of meaning and cognition and hence they motivate important aspects of how we think, reason, and imagine, and can therefore play a very important role in persuasion. In this paper we will explore how persuasive is the exploitation of image-schematic devices (i.e. image schemas and image-schema based figures, such as image-schematic metaphors and metonymies) for introducing sexism in advertising using a combined axiologicalrelevance-theoretic approach. We claim that image schemas are very often used in this type of discourse in order to persuade customers in a weakly overt or covert way.

The present paper is divided into the following sections. First, we will be devoted to the state of the art of persuasion, image schemas, axiology and Relevance Theory. Second, we will introduce the corpus under analysis and the methodology used. This section will serve to ground the empirical analysis of image schematic devices and their covert or overt communicated nature in the following section. Finally, we will draw some conclusions.

\section{State of the art}

\subsection{Persuasion and image schemas}

Persuasion as a communicative strategy is usually present at everyday situations, for example, in an advertisement, political meeting, etc. Schmidt and Kess (1986: 2) define it as "the process of inducing a voluntary change in someone's attitudes, beliefs or behaviour through the transmission of a message".

Regarding advertising persuasion, we can say that the primary goal of advertising is persuading the audience to buy a certain product. With this goal in mind, advertisers often use rhetorical devices, techniques and strategies to achieve their goals of moving their audiences and/or changing their attitudes. Different scholars have analysed advertising persuasion from different points of view (Schmidt and Kess, 1986; Tanaka 1992, 1994 (1999); Roiz Célix, 1996; Meyers-Levy and Malaviya, 1999; Fuertes-Olivera, Velasco-Sacristán, Arribas-Baño and Samaniego-Fernández, 2001; Borchers, 2002 (2005); Lee, 2008; among others). In addition, the informative and persuasive roles played by figurative language in advertising discourse have been considered by McQuarrie and Phillips (2005), Ang and Lim (2006), van Mulken, van Enschot and Hoeken (2005), van Enschot (2006), Ma (2008), Lim, Ang, Lee and Leong (in press), among others. Regarding metaphor, they have found that they are often artfully manipulated within advertisements to attract the audience's attention to perform diverse communicative functions.

Another element we should highlight due to its persuasive value is colour. The role played by colours for advertisements is of prime importance. Colour system has been a crucial factor in the understanding of embodied language (Feldman, 2006: 66). As it is an integral element of corporate and marketing communications it induces moods and emotions, influences consumers' perceptions and behaviour and helps companies position or differentiate from the competition. As Lakoff and Johnson (1999) state, colours and colour categories are not "out there" in the world but are interactional. Colour concepts and colour-based inferences are thus 
structured by our bodies and brains. Categories of cognitive colours are capable of "conveying" sensations or concepts to the person observing them. Hence they do affect how we feel and react to certain advertisements. Because we do not actively think of colours and the ideas they remind us of, the effect colours have on us is subliminal. Although we are not conscious of it all the time, this affective effect colours have on us is very powerful, as humans have been conditioned to accept colours to represent specific ideas such as the stereotypical blue for boy and pink for girl.

Other patterns that are used in advertising in order to persuade customers are image schemas (Umiker-Sebeok, 1996; Cortés de los Ríos, 2001), although their study has been scarce. As human beings are always evaluating what can be good or bad for them, advertisers fall back on these cognitive structures since the positive or negative value of each image schema is also added to the concept or picture. Image schemas are abstract representations of recurring dynamic patterns of bodily interactions that structure the way we understand the world. They are schematic and exist beneath conscious awareness.

We believe that image schematic devices are helpful in attaining the goal of persuading customers to buy a concrete product. Meyers-Levy and Malaviya (1999) reviewed the empirical research on what makes an advertisement persuasive and concluded that one way in which advertisements are persuasive is by giving their audience a pleasurable experience. As our analysis will show, image schematic devices can provide this pleasurable experience in advertising in several related ways.

It is difficult to find image schemas in isolation. Indeed, linguistic analyses have shown that image schemas can serve as source domains of countless metaphors (Lakoff and Johnson, 1980; Lakoff, 1987; Ruiz de Mendoza, 1997a and 1998; Barcelona, 2000; Peña, 2000; Hampe, 2005; Hurtienne and Israel, 2007), metonymies (Ruiz de Mendoza Ibáñez, 1997a; Díez Velasco, 2001) and metaphor-metonymy interaction cases (Ruiz de Mendoza 1997a, 1999a, 1999b, 2000).

Considering studies on persuasion and image schemas, Núñez Perucha (2003) understands the persuasion communicative domain in terms of the FORCE image schema. We think that the persuasive discourse in advertising, in the same way as that of force, is directional. It has its origin in an agent and it is addressed towards a particular listener with the aim to incite him to acquire a product or service. Image schemas are used like persuasive strategies by means of which the advertiser tries "to force" the receiver to buy. Umiker-Sebeok (1996) points out that some kinaesthetic image schemas (compulsion, blockage and containment) lie at the root of our everyday conception of power and force. Furthermore, they are used for representing gender in different respects as they are used in the structuration and the construction of gender spaces in advertising, in terms of the above mentioned kinaesthetic image schemas and in relation to different non-verbal gender displays (i.e. relative size, psychological withdrawal, ritualized subordination, function ranking, locations, touch/manipulation and movement). Núñez Perucha (2003) also analyses two image schemas (i.e. force and containment) and folk models to study their role in characterising victims in different narrative texts in English.

Taking all this into account, in the present paper we would like to place emphasis on those image schemas used in the discourse of advertising to introduce sexism since image schematic 
devices are often used to transmit asymmetrical gender values with the aim to persuade the audience. For these purposes, in our first analysis, an image-schematic one, we will follow the list of image schemas proposed by Evans and Green (2006), namely:

(a) space: up-down, front-back, left-right, near-far, centre-periphery, path, straight-curved, scale.

(b) containment: in-out, full-empty.

(c) multiplicity: part-whole, count-mass.

(d) balance: axis balance, point balance equilibrium.

(e) force: compulsion, blockage, counterforce, diversion, enablement, attraction, resistance.

(f) cycle.

(g) attribute: heavy-light, dark-bright, big-small, warm-cold, strong-weak.

This image schematic analysis also incorporates an axiological approach.

\subsection{Pragmatics, axiology and advertising}

A few relevant contributions have laid the foundations of axiological linguistics or axioematics, particularly in Cognitive Semantics. Krzeszowski (1990: 161) has pointed out the dominant function that values perform in the structure of concepts. For this scholar many lexical items carry heavy axiological weight, and that weight is semantically relevant. Furthermore, he makes a case for Lakoff's ICMs as a starting point for the development of a general theory of values. Accordingly, the level of experience constitutes the first step to configure a hierarchy of values relative to the way people evaluate situations. In addition, Krzeszoswki $(1993,1997,2004)$ argues that the axiological parameter POSITIVENEGATIVE lends special dynamism to the use of preconceptual schemata in metaphorization. From a different angle, the role of values is also explored by Pauwels and Simon Vanderbergen $(1993,1995)$. These authors focus on metaphoric projections from the domain of body-parts on to that of linguistic action. Interestingly enough, in our view, it is the emphasis that they place on context. Metaphors expressing value judgements can be grouped into two main classes: (1) context-independent value judgements, that is, prototypically positive or negative and (2) context-dependent value judgements.

Previous research in advertising discourse has established the link between contextdependent or context-independent values and advertising in many ways. Cortés de los Ríos (2001: 43-53) collects and summarises a significant amount of relevant contributions to the codification of values in advertising discourse, particularly those of Andren, Ericsson, Ohlsson and Tännsjö (1978), Pollay (1984), Khale (1986), Jhally (1987), Delbecque (1990), Bhatia (1992), Cheng and Schweitzer (1996), Caillat and Mueller (1996), among others. On the other hand, we would like to mention that Critical Discourse Analysis is gradually moving in the direction of PDA or Positive Discourse Analysis (Martin and Rose, 2003). It is a cognitive axiological approach that describes what texts 'do well' and 'get right' in our eye.

According to advertising, the advertiser must choose the qualities that are to be advertised for the product, its desired practical functions as well as the symbolic values that consumers would seek in it. Then the advertiser must decide how these qualities are to be presented in the 
advert. The problem which the advertiser faces is how to get a reader to associate the product or service with the desired image or quality. The act of buying is not a thoughtless and inconsequent action, but it is an entry into the brand's universe, suscribing to the values it conveys (Kneebone, 2002).

It is particularly relevant how previous research in the field of Cognitive Semantics has demonstrated that cognitive tools such as metaphor and metonymy play an extremely important role in advertising strategies (Ungerer, 2000; Rocamora Abellán, 2004; Velasco Sacristán and Fuertes Olivera, 2004; Forceville, 1996, 2006, among others). It is true that advertisers sometimes tend to present the positive aspects of a product to customers by verbalizing how good, excellent the product is for the customer. However, advertising prefers to establish a metaphorical link with a domain conventionally representing the desired quality (Ungerer, 2000: 325). At the same time, abstract services take shape through metaphors combining the cognitive potential of linguistic and pictorial metaphors in order to compensate for the non-existence of a tangible product by evoking feelings of trust, confidence and security (Forceville, 1996, 2006).

On the other hand, metonymy only involves one conceptual domain, that is to say, the mapping occurs within a single domain and not across domains. In metonymy there is a "stand for" relationship since one entity in a schema is taken to stand for another entity in the same domain or for the domain as a whole. Likewise, metaphor and metonymy may interact in a number of ways (Goossens, 1995; Taylor, 1995; Ruiz de Mendoza Ibáñez, 1997a, 1997b, 1998, 1999a, 1999b; Díez Velasco, 2001; Riemer, 2001; Herrero, 2002; Ruiz de Mendoza and Díez Velasco, 2003; Geeraerts, 2003). Their conceptual and semiotic interaction is of significant relevance in advertising (Cortés de los Ríos, 2001; Rocamora Abellán, 2004; Velasco Sacristán, in press, b). As well as image schemas, metaphors and metonymies, especially image-schemas based metaphors and metonymies, are capable of endowing expressions with a strong axiological value (Díez Velasco, 2001).

In our analysis, we would like to outline the fact that the plus-minus parameter shows that the second element of an image schema device sometimes is assumed to carry positive evaluations. For example, the image schema MORE IS UP (GOOD) and LESS IS DOWN (BAD), motivated by the universal experience of the piling frame in which an increase in height (UP) in a piling situation comes to be metonymically mapped onto "increases in quantity" (MORE), are inverted culturally to be paradoxically conceptualized as LESS IS GOOD being 'less' positive valued. This axiological incompatibility or axiological clash (Krewzeszowski, 1997:230) of image schemas, as used in advertising, seems to provide some empirical support for the claim that, despite many continuing discussions and debates over the very nature of image schemas and their psychological reality, images schemas are not merely representative of universal body experience, but are crucially tied to specific socio-cultural cognition (Sinha, 2002; Kimmel, 2005; Zlatev, 2005).

We will analyse image schemas and their variants in our sample using an axiological analysis, as stated above, along with a relevance theoretic analysis to determine if those image schematic devices are covert or overt communicated when used to introduce sexism. 


\subsection{Relevance Theory, covert communication and advertising}

The relevance-theoretic approach to pragmatics, presented most fully in Sperber and Wilson's (1986 (1995)) seminal work on ostensive-inferential communication, is a cognitive orientation to thought and pragmatics, governed by a single cognitive principle, the Principle of Relevance. This principle is a two-fold formulation: (1) human cognition tends to be geared to the maximisation of relevance (i.e. we pay attention only to information that seems relevant to us) and (2) every act of ostensive communication comes with a presumption of its own optimal relevance (i.e. it creates an expectation of relevance). Relevance itself is defined as a balance of 'effects' (i.e. assumptions activated) and 'effort' (i.e. attention, memory search, inference) between the communicator and the addressee of a communication process: the greater the cognitive effects, the greater its relevance whereas the greater the processing effort, the lower its relevance. This communication process is defined in terms of the recognition of intentions ${ }^{1}$, the consequent mutuality of the cognitive environment and the operation of inferential processes.

Within this framework, different figures of speech, such as image-schematic based metaphors and metonymies, are examples of "loose talk" (Sperber and Wilson, 1986 (1995): 231-237) that are the best way to achieve optimal relevance, part of which can be achieved by poetic effects. General applications of Relevance Theory to the analysis of metaphor and metonymy have been countless (Goatly, 1994; Papafragou, 1996; Radden and Kövecses, 1999; Panther and Thornburg, 2003; Panther, 2006; Gibbs and Tendahl, 2006; Wilson and Carston, 2006; Sperber and Wilson, 2008; etc.) and also several contributions have applied Relevance Theory to account for mostly metaphors in advertising (Forceville, 1994, 1996; Tanaka, 1994 (1999); Díaz Pérez, 1999; van Enschot, 2006; Velasco-Sacristán and FuertesOlivera, 2006).

This theory just described reaches beyond Sperber and Wilson's seminal work (1986 (1995)) and its most recent refinements (Sperber and Wilson, 2002; Wilson and Sperber, 2004). In fact, its implications for pragmatics have been widely explored in different textbooks, monographs and a vast number of articles ${ }^{2}$. In connection with our study, we have found that one media discourse to which Relevance Theory has been successfully applied is the discourse of advertising. Indeed, the search for relevance is a feature which advertisers exploit. In this vein, one of the first analysts that used Relevance Theory in the analysis of ads was Pateman (1983), even though Relevance Theory was still at its preliminary stages. These ideas have been developed and strengthened later by Tanaka (1992), (1994 (1999)), Díaz Pérez (1999, 2000), Melchenko (2003), Ma (2008) and Pop (2008), among others.

Relevance Theory draws a range of interesting distinctions between ostensive (overt) communication and the various forms of covert communication which advertisers often exploit (Tanaka, 1992: 100). Covert communication has been defined by Bencherif and Tanaka (1987; quoted in Tanaka 1994 (1999): 4) as "a case of communication where the intention of the speaker is to alter the cognitive environment of the hearer, i.e. to make a set of assumptions more manifest to her, without making this intention mutually manifest". In order to differentiate overt from covert communication the distinction between informative and communicative intentions, the audience's search for optimal relevance and its interest in 
cost-effectiveness are of crucial significance. First, overt communication consists of the revelation of the informative and communicative intentions whereas covert communication hides the informative intention, and hence the communicative intention, by making assumptions more manifest, but not mutually so. In other words, the speaker does not publicise his/her informative intention when he/she believes that revealing it would have an adverse effect on its fulfilment (Tanaka, 1994 (1999): 42). Second, as opposed to ostensive communication, covert communication does not have the speaker's guarantee of optimal relevance ${ }^{3}$ to guide the hearer's interpretation, but other stimuli (e.g. non-linguistic ones such as sexual images) to overcome this deficiency. Third, since processing information requires effort, the request to undertake this task has to be accompanied by reward. In overt communication the hearer gets his/her reward by deriving explicatures and implicatures ${ }^{4}$. In covert communication, on the other hand, the hearer often does not get his/her reward entirely through inference for the speaker exploits the fact that humans get a kind of pleasure out of processing the above mentioned stimuli (Sperber and Wilson, 1986 (1995): 124-125; Tanaka, 1994 (1999): 20). In addition, there is, of course, a continuum of cases in between overt and covert communication. Weak overt communication is, for example, a case in point. This is similar to covert communication in many respects: both shift responsibility for certain interpretations away from the communicator and towards the addressee. Tanaka (1994 (1999)) makes a theoretical distinction between both in terms of mutual manifestness (in weak overt communication an assumption is barely made mutually manifest or the degree of manifestness is extremely low). In advertising, both weak overt communication and covert communication play a very important role as strategies used to overcome distrust and adverse reactions (Tanaka 1994 (1999)) or skepticism (Crook, 2004) on the part of the audience to various aspects of adverts, such as the use of sexual images (Crook, 2004; Velasco-Sacristán, in press, a). They are used by advertisers to perpetrate or break certain evaluations on gender relations.

Numerous scholars have considered advertising in terms of 'covert' rather than ostensive communication (Tanaka, 1992, 1994 (1999); Fuertes-Olivera, Velasco-Sacristán, ArribasBaño and Samaniego-Fernández, 2001; Crook, 2004; van Mulken, Renske van Enschot-van Dijk and Hocken 2005; Velasco-Sacristán and Fuertes-Olivera, 2006; Lagerwerf, 2007; Pop, 2008; Sáez Rubio and Pennock Speck, 2008; Velasco-Sacristán, in press, a). They have observed that certain stimuli, such as sex, are used in place of ostension for making the advertiser's informative intention manifest, but not mutually so. According to Mills (2008) there are two forms of sexism -overt and indirect. Overt sexism is clear and unambiguous, while indirect sexism is based on pragmatics and the meaning and interpretation of utterances. The latter is extremely common.

Bearing all this in mind, in this paper we claim that image schemas and their variants (i.e. image-schematic based figures) are communicative devices that can give rise to sexist interpretations. They are often used by advertisers to introduce a value system on gender that often activates and imposes "negative" values by means of mostly covert and weakly overt communicated assumptions. We also argue that they are persuasive in so far as they show convincingly that certain effort-demanding interpretive paths are favoured in exchange for the enjoyment in getting the right meaning and value(s) of the image schematic devices. In this 
sense, as they give the audience a pleasurable experience, they are persuasive, as argued by Meyers-Levy and Malaviya (1999).

With the assistance of the explicative tools of Relevance Theory in combination with Axiology we aim to explain in this paper how image schematic devices can introduce sexism in advertising.

\section{Corpus and methodology}

\subsection{Corpus}

We have selected a sample corpus of advertisements online, 'The Advertising is Good for You' blog, created by Paula Zargaj-Reynolds ( $<$ http://pzrservices.typepad.com $>$ ), and used 10 ads from its sexist advertising section:

\section{[http://pzrservices.typepad.com/advertisingisgoodforyou/sexist_advertising]}

We have chosen print and outdoor ads from this section for practical reasons: print adverts and billboards provide a complete image and word text in a very limited space/time span. The 10 advertisements from the 'Sexist advertising' section have been selected randomly among those that introduced, or defied, sexism and included image-schematic devices (i.e. image schemas and image-schematic metaphors and metonymies in their image and/or verbal composition) and those that offered similar portrayals of men and women. They are the following advertisements:

1. 'Slim Fast'

2. 'Alpine Plastic Surgery'

3. ' $\mathrm{Zu}$ '

4. 'Pascal Pour Elle' and 'Skin Deep Medical Spa'

5. 'Dolce and Gabbana Spring/Summer 2007 ready-to-wear collection'

6. 'Fayreform'

7. 'Dove'

8. 'The Body Shop'

9. 'Duncan Quinn'

10. 'Bavaria'

\subsection{Methodology}

We will use a combined axiological-relevance-theoretic approach to analyse the persuasive nature of image schematic devices when used for introducing sexism in advertising. Our combined axiological-relevance-theoretic approach consists of two concrete analyses:

First, we will analyse image schemas considering their cognitive nature (i.e image schema or image schematic-figure: metaphor or metonymy), modality (monomodal or multimodal), 
universality-cultural specificity nature (context dependent or context independent) and we will classify them using Evans and Green's (2006) typology of image schemas. We will use Table 1 for this first analysis:

\begin{tabular}{|c|c|c|}
\hline SUB-ANALYSES & TYPES & SUBTYPES \\
\hline COGNITIVE NATURE & & \\
\hline MODALITY & & \\
\hline $\begin{array}{c}\text { UNIVERSAL-CULTURAL } \\
\text { SPECIFICITY }\end{array}$ & & \\
\hline IMAGE SCHEMA & & \\
\hline
\end{tabular}

Table 1: Axiological analysis of image schematic devices.

Second, we will explore if those image schemas and variants are communicated overtly or covertly by considering the three typical criteria for differentiating between overt and covert types of communication within a relevance-theoretic framework, namely, the distinction between informative intention and communicative intention, the audience's search for optimal relevance and their interest in cost-effectiveness. We will use Table 2 for this second analysis:

\begin{tabular}{|c|c|c|}
\hline $\begin{array}{c}\text { CRITERIA FOR OVERT- } \\
\text { COVERT } \\
\text { COMMUNICATION }\end{array}$ & YES & \\
\hline $\begin{array}{c}\text { INFORMATIVE } \\
\text { INTENTION }\end{array}$ & & \\
\hline $\begin{array}{c}\text { COMMUNICATIVE } \\
\text { INTENTION }\end{array}$ & & \\
\hline OPTIMAL RELEVANCE & & \\
\hline COST & TYPE & $\begin{array}{c}\text { SUBTYPE (only if overtly } \\
\text { communicated) }\end{array}$ \\
\hline $\begin{array}{c}\text { EFFECTIVENESS } \\
\text { OVERT-COVERT } \\
\text { COMMUNICATION }\end{array}$ & & \\
\hline
\end{tabular}

Table 2. Relevance-theoretic analysis of image schematic devices.

\section{Analysis of the corpus}

\subsection{Analysis}

AD NUMBER 1 ('SLIM FAST'):

PLATE 1:

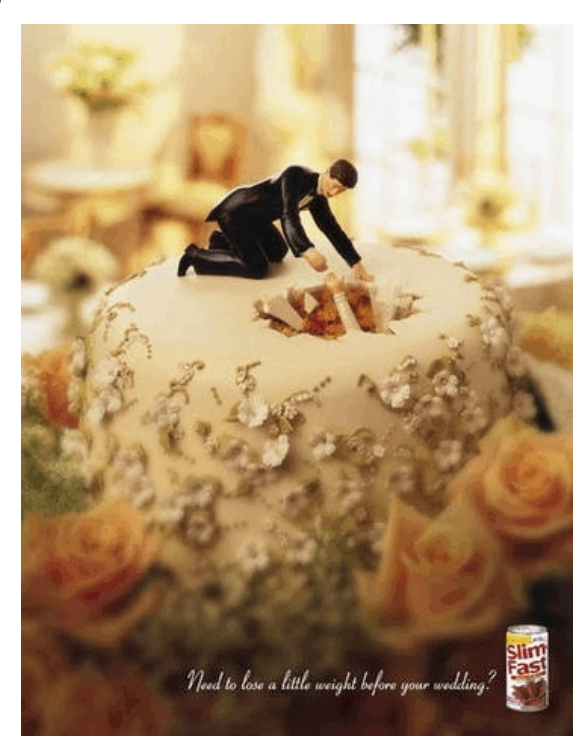




\begin{tabular}{|c|c|c|}
\hline SUB-ANALYSES & TYPES & SUBTYPES \\
\hline \multirow[t]{3}{*}{ COGNITIVE NATURE } & 1. Image schema & \\
\hline & $\begin{array}{l}\text { 2. Metaphor (i.e. A } \\
\text { WOMAN WHO } \\
\text { IS OVERWEIGHT IS } \\
\text { DOWN) }\end{array}$ & 2. Metonymy-based metaphor \\
\hline & $\begin{array}{l}\text { 3. Metonymy (i.e. } \\
\text { FEMALE ARM FOR } \\
\text { FEMALE IDENTITY) }\end{array}$ & 3. Part for whole metonymy \\
\hline \multirow[t]{3}{*}{ MODALITY } & 1. Monomodal & 1. Pictorial \\
\hline & 2. Multimodal & 2. Pictorio-verbal \\
\hline & 3. Monomodal & 3. Pictorial \\
\hline \multirow{3}{*}{$\begin{array}{l}\text { UNIVERSAL- } \\
\text { CULTURAL } \\
\text { SPECIFICITY }\end{array}$} & 1. Cultural & 1. Context-dependent \\
\hline & 2. Cultural & 2. Context-dependent \\
\hline & 3. Cultural & 3. Context-dependent \\
\hline \multirow[t]{3}{*}{ IMAGE SCHEMA } & 1. Attribute & 1. Dark-bright \\
\hline & $\begin{array}{l}\text { 2.Space/containment/ } \\
\text { balance/force/attribute }\end{array}$ & $\begin{array}{l}\text { 2. Up-down/in-out/point balance } \\
\text { equilibrium/resistance/heavy-light, big- } \\
\text { small, strong-weak }\end{array}$ \\
\hline & 3. Multiplicity & 3. Part-whole \\
\hline
\end{tabular}

\begin{tabular}{|c|c|c|}
\hline $\begin{array}{c}\text { CRITERIA FOR OVERT- } \\
\text { COVERT } \\
\text { COMMUNICATION }\end{array}$ & YES & $\mathrm{NO}$ \\
\hline $\begin{array}{c}\text { INFORMATIVE } \\
\text { INTENTION }\end{array}$ & & $\mathrm{X}$ \\
\hline $\begin{array}{c}\text { COMMUNICATIVE } \\
\text { INTENTION }\end{array}$ & & $\mathrm{X}$ \\
\hline OPTIMAL RELEVANCE & $\checkmark$ & \\
\hline COST & $\sqrt{ }$ & \\
\hline EFFECTIVENESS & TYPE & $\begin{array}{c}\text { SUBTYPE (only if overtly } \\
\text { communicated }\end{array}$ \\
\hline $\begin{array}{c}\text { OVERT-COVERT } \\
\text { COMMUNICATION }\end{array}$ & COVERT & \\
\hline
\end{tabular}

In this advert for 'Slim Fast' the advertiser intends to promote a weight loss product by associating it with women who are about to get married. This intention conforms to a cultural theme known as "normalization" that is often used in advertising. Normalization establishes a pathology of the body -quite simply, some bodies are identified as normal (typically in popular culture these are "slender" bodies) and others are labelled as abnormal, pathological bodies in need of repair (Lukas, 2002). Yet an explicit association between women and abnormal overweight bodies might be regarded as offensive and therefore the advertiser makes this intention manifest but not mutually so. In addition, the use of an image schema, an image-schematic metaphor and an image schematic metonymy make the reader's search 
for optimal relevance difficult. First, the advertiser uses the image schema of attribute, more specifically 'dark-bright', to introduce the persuasive technique of 'foregrounding'. This is the way some things in the visual composition draw our attention (i.e. the dark-dressed clay figure of the groom) while others fade in the background (i.e. the light-coloured dressed bridesmaid of almost the same colour as that of the wedding cake). Very often, 'bright' is prototypically used to foreground whereas 'dark' is used to fade, but here the advertiser has used 'dark' to highlight' the male clay figure on the wedding cake and 'bright, clear colours' to fade the female clay figure falling down inside the cake. This involves an axiological reversal as 'dark' is not prototypically positive. In addition, the metaphor A WOMAN WHO IS OVERWEIGHT IS DOWN is based on the image schemas of space (up-down), containment (in-out), balance (equilibrium), and attribute (heavy-light, dark-bright, bigsmall) in which the negative value is held by 'down', 'in', 'lack of equilibrium', 'heavy', and 'big'. We observe that there are axiological clashes with the value of 'in', 'heavy', and 'big' as those are prototypically positive values in image schemas. Those prototypical values of these image schemas are reversed to associate the metonymy-based metaphor of MORE IS DOWN with women. This metaphor contradicts the universal experience of the piling frame according to which more quantity gives rise to an increase in verticality (i.e. MORE IS UP). This reversal of prototypical values is used to introduce discrimination (i.e. normalization) against women by associating them with an excess image schema (i.e. more weight than desirable) and lack of control (i.e. falling inside the wedding cake, needing help to get out of it). Second, the metonymy of FEMALE ARM FOR FEMALE IDENTITY, based on the image schema of multiplicity -part-whole, in which 'part' is negative, is used to introduce the cultural theme of "reductionism" with regard to women. This involves reducing a woman to a collection of parts, and not accepting the uniqueness, identity, and personality of the woman (Lukas, 2002). The fact that the advertiser only shows the female clay figure arm instead of her whole body makes it possible for the advertiser to deny responsibility for communicating the assumption that she is overweight as the audience can hardly see if she is overweight. The audience get his/her reward for this extra mental effort required to processing these image schematic devices through inference and the pleasure of a witty, artful, and apparently humorous, illustration.

\section{AD NUMBER 2 ('ALPINE PLASTIC SURGERY'): PLATE 2:}

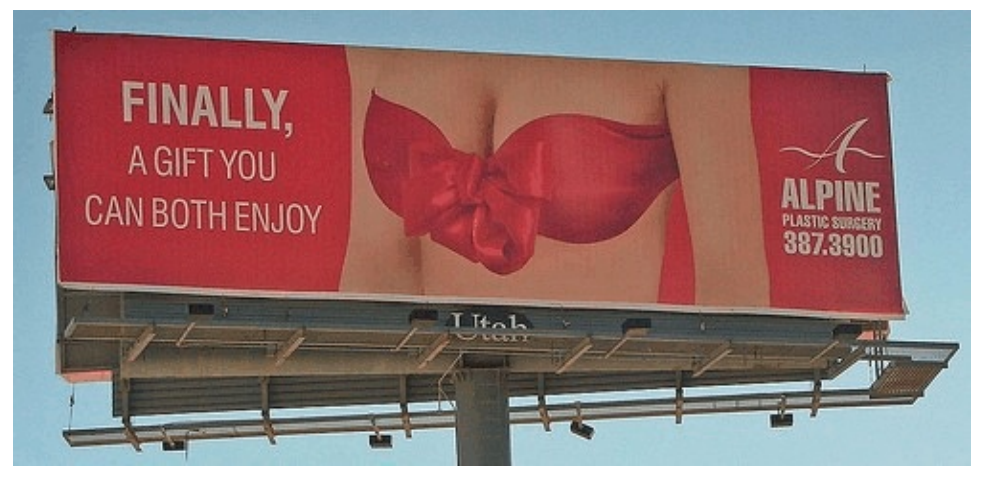




\begin{tabular}{|c|c|c|}
\hline SUB-ANALYSES & TYPES & SUBTYPES \\
\hline \multirow[t]{3}{*}{ COGNITIVE NATURE } & 1. Image schema & \\
\hline & $\begin{array}{l}\text { Metaphor (i.e. A BREAST } \\
\text { ENLARGEMENT IS A } \\
\text { GIFT) }\end{array}$ & 2. Metonymy-based metaphor \\
\hline & $\begin{array}{l}\text { 3. Metonymy (i.e. FEMALE } \\
\text { BREASTS FOR FEMALE } \\
\text { IDENTITY) }\end{array}$ & 3. Part for whole metonymy \\
\hline \multirow[t]{3}{*}{ MODALITY } & 1. Multimodal & 1. Pictorio-verbal \\
\hline & 2. Multimodal & 2. Verbo-pictorial \\
\hline & 3. Monomodal & 3. Pictorial \\
\hline \multirow{3}{*}{$\begin{array}{l}\text { UNIVERSAL- } \\
\text { CULTURAL } \\
\text { SPECIFICITY }\end{array}$} & 1. Universal & 1. Context-independent \\
\hline & 2. Cultural & 2. Context-dependent \\
\hline & 3. Cultural & 3. Context-dependent \\
\hline \multirow[t]{3}{*}{ IMAGE SCHEMA } & 1. Attribute & 1. Dark-bright, big-small \\
\hline & 2. Attribute & 2. Big-small \\
\hline & 3. Multiplicity & 3. Part-whole \\
\hline
\end{tabular}

\begin{tabular}{|c|c|c|}
\hline $\begin{array}{c}\text { CRITERIA FOR OVERT- } \\
\text { COVERT } \\
\text { COMMUNICATION }\end{array}$ & YES & NO \\
\hline $\begin{array}{c}\text { INFORMATIVE } \\
\text { INTENTION }\end{array}$ & & $\mathrm{X}$ \\
\hline $\begin{array}{c}\text { COMMUNICATIVE } \\
\text { INTENTION }\end{array}$ & & $\mathrm{X}$ \\
\hline OPTIMAL RELEVANCE & & \\
\hline COST & $\checkmark$ & \\
\hline EFFECTIVENESS & TYPE & $\begin{array}{c}\text { SUBTYPE (only if overtly } \\
\text { communicated) }\end{array}$ \\
\hline $\begin{array}{c}\text { OVERT-COVERT } \\
\text { COMMUNICATION }\end{array}$ & COVERT & \\
\hline
\end{tabular}

In this advert for 'Alpine Plastic Surgery' the informative intention that the advertiser is trying to get across (i.e. 'get plastic surgery to enlarge your breasts and improve your sexual appeal to men') is not made mutually manifest. The advertiser expects that the audience will recover weak assumptions on their own responsibility with some help from the illustration and caption, along with his/her use of the foregrounding technique. Second, the advert does not have optimal relevance as it puts the audience to a lot of effort in achieving cognitive effects worthy of their attention. The increasing effort in processing the advert is due to the ambiguity of the caption: 'Finally, a gift you can both enjoy'. Two essentially different interpretations ('a gift made to yourself that will also be enjoyed by your sexual partner' or 'a gift made by your sexual partner to be enjoyed by you and him') come simultaneously to the mind of the addressee, and they are both consistent with the principle of relevance. The advertiser is, of course, deliberately, puzzling the reader, making his/her contribution to the processing effort, 
disproportionate. Although the ambiguity remains open, the reader has other stimuli to offset his/her efforts: the illustration and the foregrounding effect of the ad. On the one hand, the illustration depicts part of the body of a woman, her breasts, wrapped with a red lace tied giving rise to the metonymy-based metaphor A BREAST ENLARGEMENT IS A GIFT, based on the image schema of attribute (big-small), with the culturally sanctioned positive value of 'big'. This metaphor and the metonymy FEMALE BREASTS FOR FEMALE IDENTITY, based on the image schema of multiplicity (part-whole), with 'whole' being positively valued, represent women in a normalising (i.e. women's breasts must be big to conform to specific societal beauty standards) and reducing manner (i.e. a woman is no greater than her breasts). On the other hand, the advertiser uses foregrounding to highlight the woman's breasts with the use of the 'red' lace (i.e. a dark colour) that matches the red of the background, and the big size of them, also highlighted by the fact that they are the only part of the female body on display, without the uniqueness of the woman face. We would like to highlight that the red colour is associated with all things intense and passionate. It is highly erotic and it is used for road signs due to its high visibility. Red brings text and images to the foreground. The large print of 'Finally' and 'Alpine' also highlights the idea of the success in 'finally' getting what a woman wants (i.e. enhancing her sexual appeal to men) and the name of the company that can make that possible. Third, the audience get reward through the kind of pleasure out of the illustration where we find the cultural ritual of exposure of the female body for male (and/or female) evaluation and the hint of 'sex' of the caption'.

AD NUMBER 3 ('ZU'):

PLATE 3:

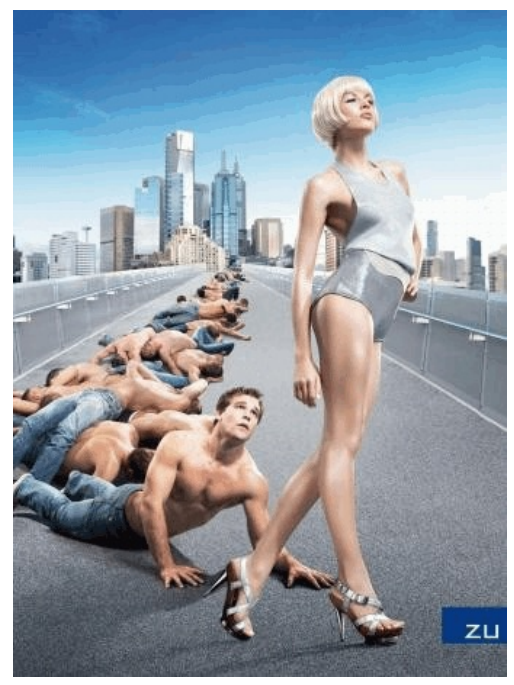

\begin{tabular}{|c|l|l|}
\hline SUB-ANALYSES & \multicolumn{1}{|c|}{ TYPES } & \multicolumn{1}{c|}{ SUBTYPES } \\
\hline COGNITIVE NATURE & 1. Image schema & \\
\cline { 2 - 3 } & $\begin{array}{l}\text { 2. Metaphor (i.e. A WOMAN } \\
\text { IS A MEN'S LEADER) }\end{array}$ & Metonymy-based metaphor \\
\hline \multirow{2}{*}{ MODALITY } & 1. Monomodal & 1. Pictorial \\
\cline { 2 - 3 } & 2. Monomodal & 2. Pictorial \\
\hline
\end{tabular}




\begin{tabular}{|c|l|l|}
\hline $\begin{array}{c}\text { UNIVERSAL- } \\
\text { CULTURAL } \\
\text { SPECIFICITY }\end{array}$ & 1. Universal & 1. Context-independent \\
\cline { 2 - 3 } & 2. Cultural & 2. Context-dependent \\
\hline IMAGE SCHEMA & 1. Space/attribute & $\begin{array}{l}\text { 1. Up-down, front-back, near- } \\
\text { far/dark-bright }\end{array}$ \\
\cline { 2 - 3 } & 2. Space/ attribute & $\begin{array}{l}\text { 2. Up-down, front-back, near-far, } \\
\text { path, scale/strong-weak }\end{array}$ \\
\hline
\end{tabular}

\begin{tabular}{|c|c|c|}
\hline $\begin{array}{c}\text { CRITERIA FOR OVERT- } \\
\text { COVERT } \\
\text { COMMUNICATION }\end{array}$ & YES & $\mathrm{NO}$ \\
\hline $\begin{array}{c}\text { INFORMATIVE } \\
\text { INTENTION } \\
\end{array}$ & $\sqrt{ }$ & \\
\hline $\begin{array}{c}\text { COMMUNICATIVE } \\
\text { INTENTION }\end{array}$ & $\sqrt{ }$ & \\
\hline OPTIMAL RELEVANCE & $\sqrt{ }$ & \\
\hline COST & $\sqrt{ }$ & \\
\hline EFFECTIVENESS & $\sqrt{ }$ & \\
\hline $\begin{array}{l}\text { OVERT-COVERT } \\
\text { COMMUNICATION }\end{array}$ & TYPE & $\begin{array}{l}\text { SUBTYPE (only if overtly } \\
\text { communicated) }\end{array}$ \\
\hline & OVERT & WEAK \\
\hline
\end{tabular}

In this advert for " $\mathrm{Zu}$ " the advertiser intends certain assumptions about his/her informative intention to become mutually but weakly manifested (i.e. women wearing the clothing and footwear advertised can make men fall at their feet). Those assumptions can be weakly inferred from the illustration. In addition, the advertisement is optimally relevant to the audience to the extent that the contextual effects achieved when it is optimally processed are large and to the extent that the effort required to process it is optimally small. The image is a stimulus that has been specifically designed to achieve cognitive effects by means of the foregrounding technique that is used to draw our attention to the woman in the front part of the picture (also taller, of a bigger size, nearer to us etc.) while the men falling behind her fade in the background, giving prototypical value to 'up', 'front', 'near' and 'bright'. As regards to colour, we can highlight the grey colour in the woman's clothes and shoes due to its association with security and solidity. This symbolic meaning transmits her superiority over men. What is more, the silver tone is related to femininity. The advertiser has used this colour to present Zu's products. With this colour he wants to focus on the feminine side of women. This illustration depicts a metonymy-based metaphor: A WOMAN IS A MEN'S LEADER, based on the image schemas of space (up-down, front-back, near-far, path and scale -firstsecond-) and attribute (strong-weak). This metaphor is used to conceptualize men and women on the basis of the scale image schema (Cortés de los Ríos, 2001: 121-122), motivated by a (probably) universal experiential association between numbers and parts of our body (i.e. two hands, two legs, one head, five fingers, etc.). This type of extension presupposes then a metonymic understanding of the sexes as fundamentally "first" or "second" that includes other image schemas such as "up-down" and "front-back" as the woman is walking upright while men are falling down behind her. "First", "up" and "front" are positively valued and 
sanctioned as positive values in our culture, whereas "second", "down" and "back" tend to bring about a feeling of weakness, lack of recognition, etc., which are negatively valued. Therefore, women, as portrayed in the image schema of the scale, space and path schemas, are seen as stronger, able, etc. This metaphor is used by the advertiser to convey a negative evaluation of men, as it helps to maintain weakly implicated assumptions regarding their helpless attraction by women who are presented as powerful. This implies objectification of men. The cultural theme of 'male objectification' seems to be a sign of advertisers recognizing the desire of women to objectify men in our society (Lukas, 2002). The processing effort is offset by the contextual effects produced by the use of a rather conventionalised, explicit (and therefore 'overt') picture of an attractive woman and attractive men that are found pleasing by both men and women.

AD NUMBER 4 ('PASCAL POUR ELLE' and 'SKIN DEEP MEDICAL SPA'): PLATE 4:

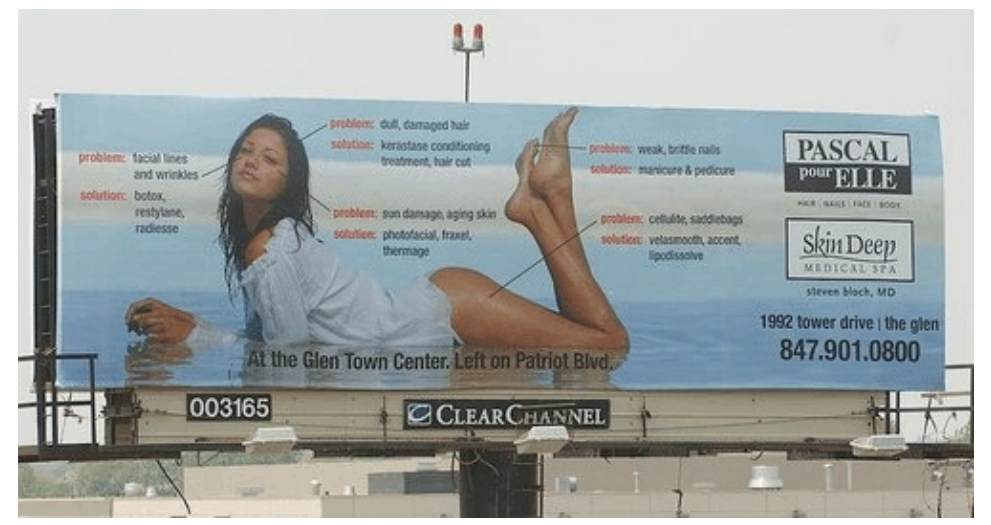

\begin{tabular}{|c|c|c|}
\hline SUB-ANALYSES & TYPES & SUBTYPES \\
\hline \multirow[t]{2}{*}{ COGNITIVE NATURE } & 1. Image schema & \\
\hline & $\begin{array}{l}\text { 2. Metonymy (i.e. A FEMALE } \\
\text { BODY FOR A WOMAN) }\end{array}$ & 2. A part for whole metonymy \\
\hline \multirow[t]{2}{*}{ MODALITY } & 1. Multimodal & 1. Pictorio-verbal \\
\hline & 2. Multimodal & 2. Pictorio-verbal \\
\hline \multirow{2}{*}{$\begin{array}{l}\text { UNIVERSAL-CULTURAL } \\
\text { SPECIFICITY }\end{array}$} & 1. Universal & 1. Context-dependent \\
\hline & 2. Universal & 2. Context-independent \\
\hline \multirow[t]{2}{*}{ IMAGE SCHEMA } & 1. Force & 1. Blockage and resistance \\
\hline & 2. Multiplicity & 2. Part-whole \\
\hline
\end{tabular}

\begin{tabular}{|c|c|c|}
\hline $\begin{array}{c}\text { CRITERIA FOR OVERT- } \\
\text { COVERT } \\
\text { COMMUNICATION }\end{array}$ & YES & \\
\hline $\begin{array}{c}\text { INFORMATIVE } \\
\text { INTENTION }\end{array}$ & & \\
\hline $\begin{array}{c}\text { COMMUNICATIVE } \\
\text { INTENTION }\end{array}$ & $\checkmark$ & \\
\hline
\end{tabular}




\begin{tabular}{|c|c|c|}
\hline OPTIMAL RELEVANCE & $\checkmark$ & \\
\hline COST & $\checkmark$ & \\
\hline EFFECTIVENESS & $\checkmark$ & $\begin{array}{c}\text { SUBTYPE (only if overtly } \\
\text { communicated) } \\
\text { OVERT-COVERT }\end{array}$ \\
COMMUNICATION & TYPE & WEAK \\
\hline
\end{tabular}

First, in this advert for "Pascal Pour Elle and Skin Deep Medical Spa" the advertiser intends, by means of the illustration, to make weakly manifest to the audience that natural beauty obstacles can be broken down by using plastic surgery and beauty treatments like the advertised ones. This intention highlights the image schema of force (blockage and resistance), with the positive value of 'resistance'. Second, the advert achieves cognitive effects with some mental effort. The advertiser describes beauty problems and offers positive worded solutions to them. Yet we encounter incongruity in the irony used as the girl depicted in the ad has not probably been in need of using any of the beauty problems promoted in the ad. As regards to colour, white is associated with light, goodness, innocence, purity, and virginity. It is considered to be the colour of perfection. Furthermore white is often associated with low weight, low-fat food, and dairy products. For this reason, the advertiser shows the image of the girl in white. There is also metonymy that reduces women to certain parts of their bodies (i.e. A FEMALE BODY FOR A WOMAN), based on the multiplicity image schema (part-whole) in which 'part' is valued negatively. The advert celebrates achievement of "body perfection", but only to a limited degree, emphasizing beautification by means of normalisation, reductionism and objectification. In advertising we see numerous examples of women exposed in water, often in very sexualized situations. In fact, a very standard apparatus of heterosexual male fantasy is that of the wet woman (Lukas, 2002). Last, the processing effort involved in processing the ad is offset by the pleasure of the explicit, conventionalised, overt picture of a young, attractive woman, exposed for male (and/or) female evaluation and the hint of "sex" suggested by her exposition in water.

AD NUMBER 5 ('DOLCE \& GABBANA SPRING/SUMMER 2007 READY-TO-WEAR COLLECTION'):

PLATE 5:

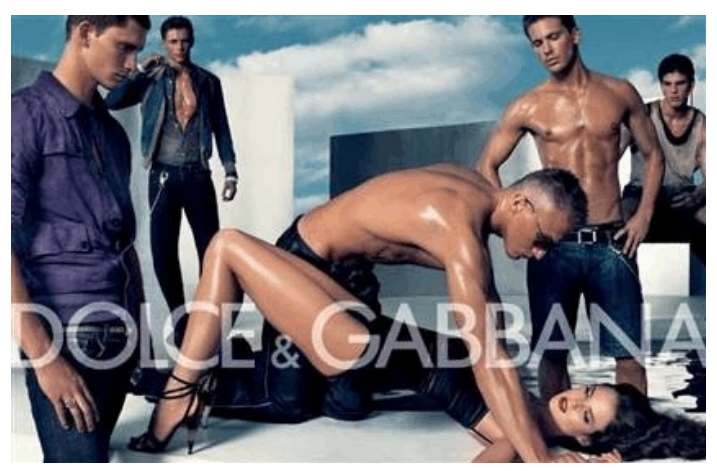




\begin{tabular}{|c|c|c|}
\hline SUB-ANALYSES & TYPES & SUBTYPES \\
\hline \multirow[t]{3}{*}{ COGNITIVE NATURE } & $\begin{array}{l}\text { 1. Metaphor (i.e. MALE SEX } \\
\text { IS VIOLENCE) }\end{array}$ & 1. Metonymy-based metaphor \\
\hline & $\begin{array}{l}\text { 2. Metaphor (i.e. MAN IS } \\
\text { FIRST) }\end{array}$ & 2. Metonymy-based metaphor \\
\hline & $\begin{array}{l}\text { 3. Metaphor (i.e. A WOMAN } \\
\text { IS SECOND) }\end{array}$ & 3. A metonymy-based metaphor \\
\hline \multirow[t]{3}{*}{ MODALITY } & 1. Monomodal & 1. Pictorial \\
\hline & 2. Monomodal & 2. Pictorial \\
\hline & 3. Monomodal & 3. Pictorial \\
\hline \multirow{3}{*}{$\begin{array}{l}\text { UNIVERSAL-CULTURAL } \\
\text { SPECIFICITY }\end{array}$} & 1. Cultural & 1. Context-dependent \\
\hline & 2. Universal & 2. Context-independent \\
\hline & 3. Universal & 3. Context-independent \\
\hline \multirow[t]{3}{*}{ IMAGE SCHEMA } & 1. Force/attribute & $\begin{array}{l}\text { 1. Blockage-resistance/strong- } \\
\text { weak }\end{array}$ \\
\hline & 2. Space/force/attribute & $\begin{array}{l}\text { 2. Up-down/blockage- } \\
\text { resistance/strong-weak- }\end{array}$ \\
\hline & 3. Space/force/attribute & $\begin{array}{l}\text { 2. Up-down/blockage- } \\
\text { resistance/strong-weak }\end{array}$ \\
\hline
\end{tabular}

\begin{tabular}{|c|c|c|}
\hline $\begin{array}{c}\text { CRITERIA FOR OVERT- } \\
\text { COVERT } \\
\text { COMMUNICATION }\end{array}$ & YES & NO \\
\hline $\begin{array}{c}\text { INFORMATIVE } \\
\text { INTENTION }\end{array}$ & & $\mathrm{X}$ \\
\hline $\begin{array}{c}\text { COMMUNICATIVE } \\
\text { INTENTION }\end{array}$ & & $\mathrm{X}$ \\
\hline OPTIMAL RELEVANCE & $\checkmark$ & $\mathrm{X}$ \\
\hline COST & TYPE & X \\
\hline EFFECTIVENESS & COVERT & $\begin{array}{c}\text { SUBTYPE (only if overtly } \\
\text { communicated }\end{array}$ \\
\hline $\begin{array}{c}\text { OVERT-COVERT } \\
\text { COMMUNICATION }\end{array}$ & & \\
\hline
\end{tabular}

In this advert for "Dolce \& Gabbana" the advertiser's informative intention (i.e. 'buy this product if you want to recreate a male sexual fantasy and highlight the beauty of our collection') is not publicised. This intention was misunderstood by the audience that interpreted the ad as a recreation of a stylised gang rape of a woman. As a result, the advertisement brought the ire of women's right groups around the world and was initially banned in Italy and Spain and eventually withdrawn from every country. In addition, the ad does not have optimal relevance as it puts the audience to a lot of effort and the contextual effects achieved do not offset that effort. The stimulus used -an image of a woman being pinned to the ground by her wrists by a bare-chested man, with other men in the background looking on- evoked the representation of violence and abuse of a woman. As regards to colour, black has been used in the woman's clothing due to its association with the feminine passive 
force. This image also portrayed men as the stronger and more powerful sex, thus giving rise to the metonymy-based metaphors of A MAN IS FIRST vs A WOMAN IS SECOND -based on the image schemas of space -up-down-, force -blockage-resistance and attribute -strongweak with the positive value of 'up', 'blockage', and 'strong'. These metaphors are related to the also metonymy-based metaphor of MALE SEX IS VIOLENCE, based on the image schemas of force (blockage-resistance) and attribute (strong-weak) with the positive value of 'blockage' and 'strong' These two image-schematic metaphors and the objectification of women as sexual objects seem to derive from a similar source: the patriarchal privileging of violence and conflict in the construction of masculinity. A masculinity that involves a dual defamation of women as sex objects and maintenance of male sexual superiority. The audience do not get any reward from the processing of the advert as the contextual effects derived from the image are found offensive.

AD NUMBER 6 ('FAYREFORM'): PLATE 6:

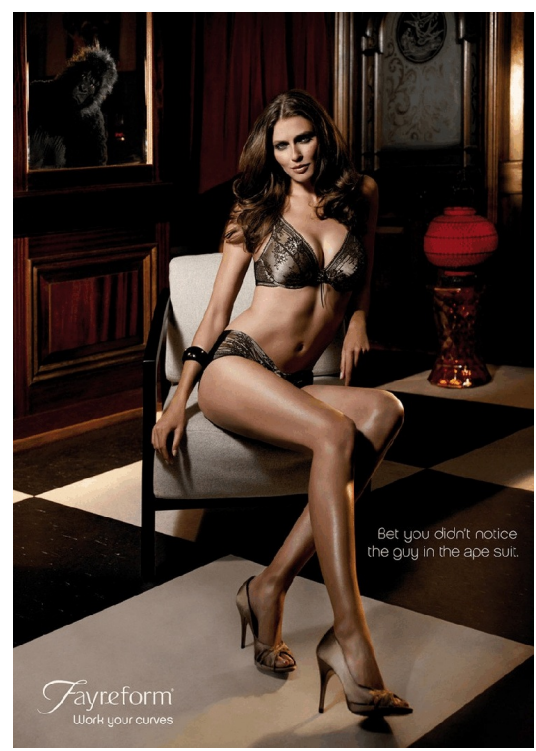

\begin{tabular}{|c|l|l|}
\hline SUB-ANALYSES & \multicolumn{1}{|c|}{ TYPES } & \multicolumn{1}{|c|}{ SUBTYPES } \\
\hline COGNITIVE NATURE & 1. Image schema & \\
\cline { 2 - 3 } & $\begin{array}{l}\text { 2. Metonymy (i.e. FEMALE } \\
\text { CURVES FOR FEMALE } \\
\text { IDENTITY) }\end{array}$ & 3. A part for whole metonymy \\
\hline MODALITY & 1. Multimodal & 1. Verbo-pictorial \\
\cline { 2 - 3 } $\begin{array}{c}\text { 2. Multimodal } \\
\text { SPECIFICITY }\end{array}$ & 1. Universal & 1. Verbo-pictorial \\
\cline { 2 - 3 } $\begin{array}{c}\text { IMAGE SCHEMAt-independent } \\
\text { 2. Cultural }\end{array}$ & 1. Space/attribute & $\begin{array}{l}\text { 2. Context-dependent } \\
\text { periphery, straight-curved, } \\
\text { scale/dark-bright, big-small }\end{array}$ \\
\hline & 2. Space,/multiplicity/attribute & $\begin{array}{l}\text { 3. Straight-curve/part- } \\
\text { whole/strong-weak }\end{array}$ \\
\hline
\end{tabular}




\begin{tabular}{|c|c|c|}
\hline $\begin{array}{c}\text { CRITERIA FOR OVERT- } \\
\text { COVERT } \\
\text { COMMUNICATION }\end{array}$ & YES & NO \\
\hline $\begin{array}{c}\text { INFORMATIVE } \\
\text { INTENTION }\end{array}$ & & $\mathrm{X}$ \\
\hline $\begin{array}{c}\text { COMMUNICATIVE } \\
\text { INTENTION }\end{array}$ & & $\mathrm{X}$ \\
\hline OPTIMAL RELEVANCE & & $\mathrm{X}$ \\
\hline COST & $\checkmark$ & \\
\hline EFFECTIVENESS & $\sqrt{\text { TYPE }}$ & $\begin{array}{c}\text { SUBTYPE (only if overtly } \\
\text { communicated) }\end{array}$ \\
\hline $\begin{array}{c}\text { OVERT-COVERT } \\
\text { COMMUNICATION }\end{array}$ & COVERT & \\
\hline
\end{tabular}

In this advert the advertiser's informative intention (i.e. 'buy and wear this product if you want to be a primary target for men's visual inspection') is manifest but not mutually so. The advertiser uses foregrounding by means of the visual stimulus of the image -an underwearclad woman posing on a chair in the front part of the picture- and a caption that highlights the foregrounding technique being used: 'Bet you didn't notice the guy in the ape suit'. This is based on the image schemas of space, more specifically front-back, near-far, centre-periphery, straight-curved and attribute -dark-bright and big-small-, with the positive value of 'front', 'near', 'centre', 'curved', 'scale', 'bright' and 'big'. As regards to colour, we should highlight the brown colour in the woman's underwear as this colour is associated with sensuality. There is no optimal relevance, but the audience receives a reasonable pay-off for their efforts at interpretation, in terms of the number of contextual effects produced. The image of a sexy underwear-clad woman as a primary target for male (and/or female) visual inspection is an effective attention-grabbing device, which serves as input to further inferential processes with regard to the caption: 'Bet you didn't notice the guy in the ape suit'. This caption deliberately teases the audience, making their contribution to the processing effort somewhat enormous. The audience then notices the presence of the guy in the ape suit on a picture hang on one of walls of the indoors scene. In addition, the ad connects the product to a female spectator reduced to a sexualized body (i.e. FEMALE CURVES FOR FEMALE IDENTITY - based on the image schemas of space -straight-curved; multiplicity -part-whole; and attribute -strongweak, with the positive meaning of curved, whole and strong) as inferred by the slogan: 'Work your curves': a form of biopower. The positive value of 'curves' introduces an 'axiological clash' as curves are prototypically valued as 'negative'. Women can use this body power to get what they want. This implies reductionism and objectification of women. Therefore, the image, caption and slogan remain vital to the reward aspect of the ad, as they are probably perceived as pleasing and ingenious due to the attractiveness of the woman on display along with the overall fogregrounding technique used by the advertiser. 
AD NUMBER 7 ('DOVE'): PLATE 7:

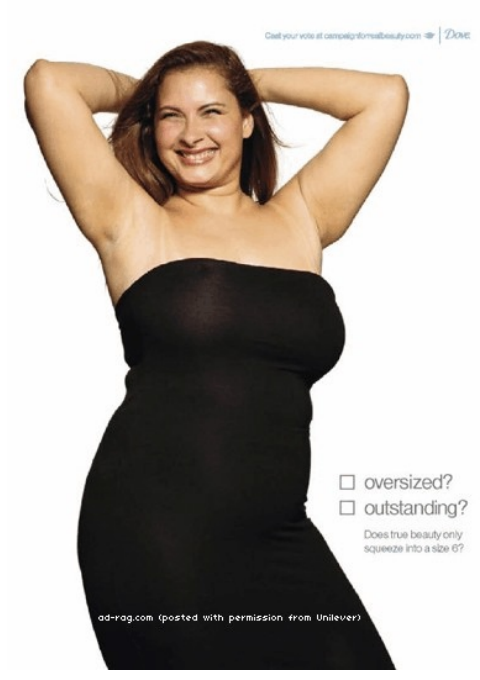

\begin{tabular}{|c|c|c|}
\hline SUB-ANALYSES & TYPES & SUBTYPES \\
\hline \multirow[t]{2}{*}{ COGNITIVE NATURE } & 1. Image schema & \\
\hline & $\begin{array}{l}\text { 2. Metonymy (i.e. A WOMAN } \\
\text { WHO IS OVERWEIGHT IS } \\
\text { AN OUTSTANDING } \\
\text { WOMAN) }\end{array}$ & 2. A part for whole metonymy \\
\hline \multirow[t]{2}{*}{ MODALITY } & 1. Multimodal & 1. Verbo-pictorial \\
\hline & 2. Multimodal & 2. Verbo-pictorial \\
\hline \multirow{2}{*}{$\begin{array}{l}\text { UNIVERSAL-CULTURAL } \\
\text { SPECIFICITY }\end{array}$} & 1. Cultural & 1. Context-dependent \\
\hline & 2. Cultural & 2. Context-dependent \\
\hline \multirow[t]{2}{*}{ IMAGE SCHEMA } & 1. Force & 1 Blockage-resistance \\
\hline & 2. Space/containment & 2. Centre-periphery/in-out \\
\hline
\end{tabular}

\begin{tabular}{|c|c|c|}
\hline $\begin{array}{c}\text { CRITERIA FOR OVERT- } \\
\text { COVERT } \\
\text { COMMUNICATION }\end{array}$ & YES & NO \\
\hline $\begin{array}{c}\text { INFORMATIVE } \\
\text { INTENTION }\end{array}$ & $\checkmark$ & \\
\hline $\begin{array}{c}\text { COMMUNICATIVE } \\
\text { INTENTION }\end{array}$ & $\checkmark$ & \\
\hline OPTIMAL RELEVANCE & $\checkmark$ & \\
\hline COST & $\checkmark$ & $\begin{array}{c}\text { SUBTYPE (only if overtly } \\
\text { communicated } \\
\text { STRONG }\end{array}$ \\
\hline $\begin{array}{c}\text { EFFECTIVENESS } \\
\text { OVERT-COVERT }\end{array}$ & TYPE & $\checkmark$ \\
\hline
\end{tabular}

First, this advert "Dove" is attempting to eradicate advertisements objectifying women and portraying unrealistic standards of airbrushed beauty. This intention is all too manifest and highlights the image schema of force, more specifically that of breaking down barriers (i.e. 
'blockage') by offering resistance. The advert was specifically designed to provoke discussion and encourage debate about the nature of beauty as part of an all encompassing program involving a unique advertising campaign featuring six real women representing beauty stereotypes (i.e. cases of metonymy where a subcategory has a socially recognized status as standing for the category as a whole). As part of the campaign the audience are asked to vote online (i.e. 'Cast your vote at campaignforrealbeauty.com') and comment on the stereotype portrayed. This is the ad questioning if the girl in the picture is oversized or outstanding. An additional question appear below: "Does true beauty only squeeze into a size 6?". Second, the advert has optimal relevance as the contextual effects achieved when the ad is processed are large and the effort required to process it optimally is small. The nonverbal image of the woman in the picture is eye catching as it shows an average, everyday woman who does not conform to the traditional standards of slenderness in the advertising industry, depicting the metonymy A WOMAN WHO IS OVERWEIGHT IS AN OUTSTANDING WOMAN, based on the image schema of space (centre-periphery) and that of containment (in-out), with the positive value of 'periphery' (i.e. far from the societal accepted cannon of beauty) and 'in' (i.e. being accepted as belonging to our society). The positive value of 'periphery' introduces an axiological clash with regard to the prototypically and culturally sanctioned negative value of 'periphery' with regard to beauty standards. As regards to colour, black is associated with elegance and with the visual effect of slimness. Here the advertiser has used this colour to present an outstanding woman dressing elegantly in black. This advert succeeds in engaging an audience that are not used to this type of adverts portraying women's real bodies as normal, beautiful ones. It is likeable and offers a clear reward for watching it as it defies typical 'normalization' in advertising (cf. ads number 1, 2, 3, 4, 5 and 6). It shows a positive shift in the gender landscape of advertising.

\section{AD NUMBER 8 ('THE BODY SHOP'):}

PLATE 8:

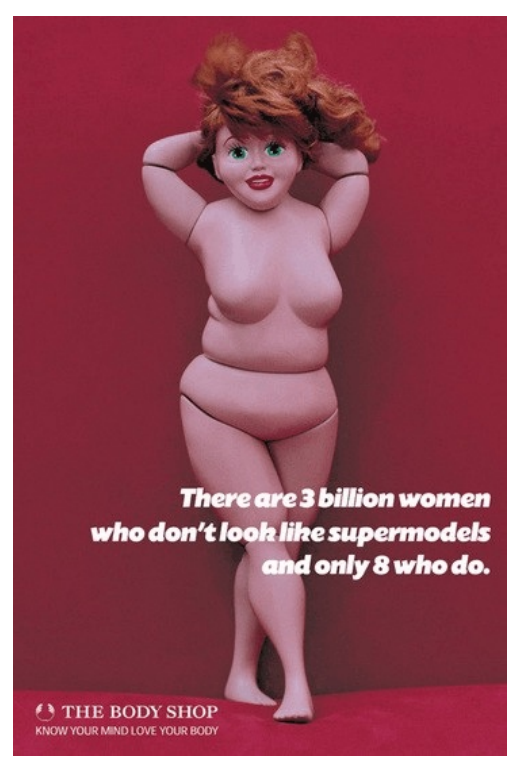




\begin{tabular}{|c|c|c|}
\hline SUB-ANALYSES & TYPES & SUBTYPES \\
\hline \multirow[t]{2}{*}{ COGNITIVE NATURE } & 1. Image schema & \\
\hline & $\begin{array}{l}\text { 2. Metonymy (i.e. A WOMAN } \\
\text { WHO DOES NOT } \\
\text { CONFORM TO } \\
\text { SUPERMODEL } \\
\text { STANDARDS OF BEAUTY } \\
\text { IS A SELF-ESTEEMED } \\
\text { WOMAN) }\end{array}$ & 2. A part for whole metonymy \\
\hline \multirow[t]{2}{*}{ MODALITY } & 1. Multimodal & 1. Verbo-pictorial \\
\hline & 2. Multimodal & 2. Verbo-pictorial \\
\hline \multirow{2}{*}{$\begin{array}{l}\text { UNIVERSAL-CULTURAL } \\
\text { SPECIFICITY }\end{array}$} & 1. Cultural & 1. Context-dependent \\
\hline & 2. Cultural & 2. Context-dependent \\
\hline \multirow[t]{2}{*}{ IMAGE SCHEMA } & 1. Force & 1 Blockage-resistance \\
\hline & 2. Space/containment/attribute & $\begin{array}{l}\text { 2. Centre-periphery, straight- } \\
\text { curved/in-out/big-small, strong- } \\
\text { weak, dark-bright, heavy-light }\end{array}$ \\
\hline $\begin{array}{c}\text { CRITERIA FOR OVERT- } \\
\text { COVERT } \\
\text { COMMUNICATION }\end{array}$ & YES & $\mathrm{NO}$ \\
\hline $\begin{array}{c}\text { INFORMATIVE } \\
\text { INTENTION }\end{array}$ & $\sqrt{ }$ & \\
\hline $\begin{array}{c}\text { COMMUNICATIVE } \\
\text { INTENTION }\end{array}$ & $\sqrt{ }$ & \\
\hline OPTIMAL RELEVANCE & $\sqrt{ }$ & \\
\hline COST & $\sqrt{ }$ & \\
\hline EFFECTIVENESS & $\sqrt{ }$ & \\
\hline \multirow[t]{2}{*}{$\begin{array}{l}\text { OVERT-COVERT } \\
\text { COMMUNICATION }\end{array}$} & TYPE & $\begin{array}{l}\text { SUBTYPE (only if overtly } \\
\text { communicated) }\end{array}$ \\
\hline & OVERT & STRONG \\
\hline
\end{tabular}

This advert is very similar to the previous one. In it the illustration, caption and slogan make all too manifest the advertiser's informative intention: women should be proud not to fit the mold of an unattainable ideal of beauty (i.e. that of supermodels). In the processing of the advert large contextual effects are achieved and the effort required to process it is small. The illustration, caption and slogan are optimally relevant. The ad portrays an illustration of a naked female mannequin that is neither slim, nor tall, posing in a typical sexually arresting pose as supermodels often use (irony is intended there) giving rise, along with the caption of "There are 3 billion women who don't look like supermodels and only 8 who do" (hyperbole is appreciated there), to the metonymy A WOMAN WHO DOES NOT CONFORM TO SUPERMODEL STANDARDS FOR BEAUTY IS A SELF-ESTEEMED WOMAN, based on the image schemas of space (centre-periphery) and containment (in-out) again with a positive meaning of 'periphery' and 'in'. Finally, the slogan contains a sentence that reminds us of the well-known aforism mens sana in corpore sano. The reward dimension is achieved 
again, as in the former ad, by the use of a non typical image of a female body as normal and beautiful, a hyperbole about supermodels and a witty slogan. The ad is also likeable and pleasing to watch as it criticises mainstream normalization in popular advertising and invites women to enhance their self-esteem.

\section{AD NUMBER 9 ('DUNCAN QUINN')} PLATE 9:

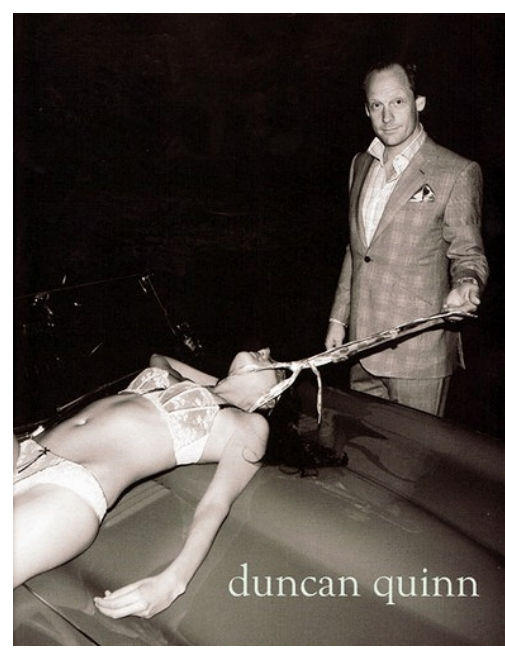

\begin{tabular}{|c|c|c|}
\hline SUB-ANALYSES & TYPES & SUBTYPES \\
\hline \multirow[t]{3}{*}{ COGNITIVE NATURE } & $\begin{array}{l}\text { 1. Metaphor (i.e. MALE SEX } \\
\text { IS VIOLENCE) }\end{array}$ & 1. A metonymy-based metaphor \\
\hline & $\begin{array}{l}\text { 2. Metaphor (i.e. A MAN IS } \\
\text { FIRST) }\end{array}$ & 2. A metonymy-based metaphor \\
\hline & $\begin{array}{l}\text { 3. Metaphors (i.e. A WOMAN } \\
\text { IS SECOND) }\end{array}$ & 3. A metonymy-based metaphor \\
\hline \multirow[t]{3}{*}{ MODALITY } & 1. Monomodal & 1. Pictorial \\
\hline & 2. Monomodal & 2. Pictorial \\
\hline & 3. Monomodal & 3. Pictorial \\
\hline \multirow{3}{*}{$\begin{array}{l}\text { UNIVERSAL- } \\
\text { CULTURAL } \\
\text { SPECIFICITY }\end{array}$} & 1. Cultural & 1. Context-dependent \\
\hline & 2. Universal & 2. Context-independent \\
\hline & 3. Universal & 3. Context-independent \\
\hline \multirow[t]{3}{*}{ IMAGE SCHEMA } & 1. Force/attribute & $\begin{array}{l}\text { 1. Strength-weak/blockage- } \\
\text { resistance }\end{array}$ \\
\hline & 2. Space/force/attribut & $\begin{array}{l}\text { 2. Up-down, scale/blockage- } \\
\text { resistance/strong-weak }\end{array}$ \\
\hline & 3. Space/force/attribute & $\begin{array}{l}\text { 3. Up-down, scale/blockage- } \\
\text { resistance/strong-weak }\end{array}$ \\
\hline
\end{tabular}

\begin{tabular}{|c|c|c|}
\hline $\begin{array}{c}\text { CRITERIA FOR } \\
\text { OVERT-COVERT } \\
\text { COMMUNICATION }\end{array}$ & YES & $\mathrm{NO}$ \\
\hline $\begin{array}{l}\text { INFORMATIVE } \\
\text { INTENTION }\end{array}$ & & $\mathrm{X}$ \\
\hline $\begin{array}{l}\text { COMMUNICATIVE } \\
\text { INTENTION }\end{array}$ & & $X$ \\
\hline
\end{tabular}




\begin{tabular}{|c|c|c|}
\hline OPTIMAL RELEVANCE & & X \\
\hline COST & $\checkmark$ & $X$ \\
\hline EFFECTIVENESS & & TYPE \\
OVERT-COVERT & SUBTYPE (only if overtly \\
COMMUNICATION & COVERT & \\
\hline
\end{tabular}

The advertiser intends to affect the mutual cognitive environment of the audience by informing them of assumptions about violence over women, displaying male power in the situation of a captive woman, suggesting that men can capture a woman, akin to a fish, by using clothes as a lure (i.e. an-image schematic metonymy-based metaphor: MALE SEX IS VIOLENCE, grounded on the image schemas of force -blockage and resistance and attribute -strong weak, with the positive value of 'blockage' and 'strong'), but wishes to avoid the social implications of making this intention all too manifest. The advertiser seemed to have calculated that this advertisement would not be too offensive for such an audience, but that was wrong as the advert turned out to be considered as the most disturbing ad of 2008 . In addition, the audience does not have optimal relevance but the stimulus of the image of the objectification and victimisation of the woman -a strangled, dead-looking, underwear-clad woman, lying on the roof of a car, being dragged by a man who wears a suit by Duncan Quinnto overcome this deficiency. The advertiser relies on the addressee noticing the power of the pictorial composition, but it puts the audience to a lot of mental effort that is not offset in terms of the number of contextual effects produced. As regards colours, we can see the advertiser has used white underwear for the girl probably due to its association with innocence. She is an innocent victim at the hands of a violent man. As well, the colours used in the background (black and grey tones) reinforce "dark" intentions of the male. Women are presented as weaker than men through the pictorial composition of the ad and through the particular situation of the scene (i.e. A MAN IS FIRST vs A WOMAN IS SECOND metaphors, based on the image schemas of space -up-down, scale-, force -blockage- and attribute-strong-weak, with the positive meaning of 'up', 'scale' and 'blockage'). Women are portrayed as captured objects, less-than-human, humiliated and suffering from male violence. As a result, the addressee does not get any reward out of processing this ad. The ad is found insulting, disrespectful and outrageously degrading to women.

AD NUMBER 10

('BAVARIA')

PLATE 10:

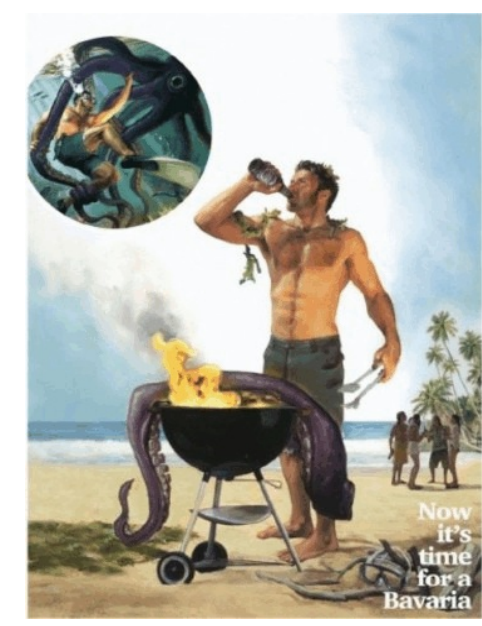




\begin{tabular}{|c|c|c|}
\hline SUB-ANALYSES & TYPES & $\begin{array}{l}\text { SUBTYPES } \\
\end{array}$ \\
\hline \multirow[t]{2}{*}{ COGNITIVE NATURE } & $\begin{array}{l}\text { 1. Metaphor (i.e. A MAN IS A } \\
\text { HERO) }\end{array}$ & 1. Metonymy-based metaphor \\
\hline & $\begin{array}{l}\text { 2. Metonymy (i.e. A MALE } \\
\text { BODY IS A MALE } \\
\text { IDENTITY) }\end{array}$ & 2. A part for whole metonymy \\
\hline \multirow[t]{2}{*}{ MODALITY } & 1. Monomodal & 1. Pictorial \\
\hline & 2. Monomodal & 2. Pictorial \\
\hline \multirow{2}{*}{$\begin{array}{l}\text { UNIVERSAL-CULTURAL } \\
\text { SPECIFICITY }\end{array}$} & 1. Cultural & 1. Context-dependent \\
\hline & 2. Cultural & 2. Context-dependent \\
\hline \multirow[t]{2}{*}{ IMAGE SCHEMA } & 1. Force/Attribute & 1 Enablement/strong-weak \\
\hline & 2. Space/attribute & $\begin{array}{l}\text { 2. Straight-curved/ heavy-light, } \\
\text { strong-weak }\end{array}$ \\
\hline
\end{tabular}

\begin{tabular}{|c|c|c|}
\hline $\begin{array}{c}\text { CRITERIA FOR OVERT- } \\
\text { COVERT } \\
\text { COMMUNICATION }\end{array}$ & YES & NO \\
\hline $\begin{array}{c}\text { INFORMATIVE } \\
\text { INTENTION }\end{array}$ & $\checkmark$ & \\
\hline $\begin{array}{c}\text { COMMUNICATIVE } \\
\text { INTENTION }\end{array}$ & $\checkmark$ & \\
\hline OPTIMAL RELEVANCE & $\checkmark$ & \\
\hline COST & $\checkmark$ & $\checkmark$ \\
\hline EFFECTIVENESS & $\checkmark$ & $\begin{array}{c}\text { SUBTYPE (only if overtly } \\
\text { communicated } \\
\text { STRONG }\end{array}$ \\
\hline $\begin{array}{c}\text { OVERT-COVERT } \\
\text { COMMUNICATION }\end{array}$ & OVERT & \\
\hline
\end{tabular}

In this advert for "Bavaria" the advertiser provides strong evidence for his/her informative intention (i.e. 'buy this product and enjoy it after extreme physical activity'). Furthermore, the ad bears a guarantee of optimal relevance as it achieves the greatest contextual effects and requires the smallest processing effort. The illustrations depict stereotypical images of masculinity (i.e. the metonymy A MALE BODY IS A MALE IDENTITY, based on the image schemas of space -straight-curved-and attribute -heavy-light and strong-weak, giving positive value to 'curves', 'heavy' and 'strong'). The first is prototypically sanctioned as negative, thus introducing an axiological clash. The man is bare-chested in both illustrations, showing his muscles and abdomen; these are related to the idea of strength. We can observe reductionism applied to men in this case, showing also some normalization with regard to the male body (i.e. muscles, broad-shoulders, etc.). This macho model that acts tough has a lot of currency in today popular culture (e.g. comics, etc.) (i.e. the metaphor A MAN IS A HERO, based on the image schemas of force -enablement and attribute -strong-weak, with the traditional positive meaning of 'enablement', and 'group'). The utterance of the slogan leads to an interpretation consistent with the principle of relevance as it implies that after extreme physical activity the product advertised is a good reward. The pictorial illustrations of the ad (similar to those of comics), showing an attractive and physically appealing man, act as a 
reward to the addressee's request for attention and effort in interpreting the ad. The audience are likely to find the ad pleasing and entertaining.

\section{Conclusions and results}

Our analyses have proved that many present ads reflect solidified and predictable stereotypes of bodies, themes and behaviours by means of different image schematic devices. They are used either alone, as an overall persuasive strategy, mostly the attribute image schema of 'dark-bright' used for foregrounding male or female figures in the composition while fading others in the background and the force image, more specifically 'resistance' when the advertiser uses the product as a force against certain beauty problems or when he/she uses the whole ad to resist certain cultural themes often used in advertising to introduce sexism against women, such as normalisation or reductionism. More often, however, image schemas are part of the source domains of metaphors and metonymies used in many excessively sexual advertisements offensive to women that celebrate normalisation, objectification and reductionism, as well as those that picture men in powerful and violent positions over women. In contrast, some image-schematic metaphors and metonymies are appearing to discriminate against men by means of normalisation and reductionism, and some image-schematic metonymies are now being used to eradicate the normalisation and reductionism themes by promoting a healthy body image of women.

The image schemas that have appeared in our analyses as more connected with the discriminatory cultural themes of normalisation, reductionism, objectification and mysogynism (i.e. use of violence over women) have been those of space (e.g. up-down; frontback; near-far; centre-periphery; straight-curved; and scale), multiplicity (part-whole), force (blockage-resistance) and attribute (heavy-light; dark-bright; big-small; and strong-weak). The space and attribute image schemas have often appeared in image-schematic metonymybased metaphors and the multiplicity image schema (part-whole) has been found in all image schematic metonymies. In addition, we have found specific emphases on values in the ads under analysis. Some of the prototypically positive values of some image schemas have often been used with a negative value (e.g. heavy, dark, curved, etc.) thus producing axiological clashes and proving that they are not merely representative of universal experience, but crucially tied to specific socio-cultural cognition. In addition, the image schematic devices analysed have been mostly multimodal (i.e. pictorio-verbal and verbo-pictorial), although we have found some monomodal ones, pictorial, used when introducing certain discriminatory themes like violence over women.

Most of these schematic devices are communicated covertly (50\%) or weakly overt (20\%). They are covertly and weakly overt communicated when introducing normalisation, reductionism, objectification and mysogynism and they are strongly overtly communicated when used against normalisation and reductionism and in some cases of male normalisation and reductionism (30\%). Although they involve additional processing effort this has often been offset by the extra cognitive effects achieved in processing the ad and 'getting' the right meaning and value(s). This pleasurable experience works for most of the adverts under the 
analysis, except for two cases of discrimination using mysogynism (i.e. ads numbers 5 and 9) that are found degrading, offensive and demeaning to women.

This paper has proved that image schematic devices are used persuasively to introduce sexism in the advertisements analysed, mostly the image schemas of space, force, multiplicity and attribute, and mostly by means of covert and weakly overt forms of communication.

These image schematic devices often reverse prototypical values, universally sanctioned as positive or negative, to introduce discriminatory cultural themes such as normalisation, reductionism, objectification and mysogynism. They therefore seem to be not merely representative of universal experience, but crucially tied to specific socio-cultural cognition, as also suggested by Sinha (2002), Kimmel (2005) and Zlatev (2005).

Special cognitive effort and effects are involved with understanding these image schematic devices. Yet, although they seem to contradict a formal application of the Principle of Relevance, as they involve additional processing effort, this is often offset by the extra effects like the pleasure in processing the ad and 'getting' the right meaning and value(s). This pleasurable experience is one important way in which advertisements are persuasive (MeyersLevy and Malaviya, 1999).

Our analyses have also shown the following gendered landscape: there are many excessively sexual advertisements offensive to women that celebrate normalisation, objectification and reductionism, as well as those which picture men in powerful or violent positions over women. In addition, new ads are now using image schematic devices to introduce some forms of normalisation, objectification and reductionism of men while others are fighting to eradicate normalisation and reductionism of women, by promoting a healthy body image of women.

\section{Notes}

1. Sperber and Wilson (1986 (1995)) defined these two types of intentions as follows: 'informative intention' is "the intention to make manifest or more manifest to the audience a certain set of assumptions" (1986 (1995): 58) and 'communicative intention' is "the intention to make mutually manifest to audience and communicator the communicator's informative intention" (1986 (1995): 61).

2. See Yus Ramos (1998) and also his RELEVANCE THEORY ONLINE BIBLIOGRAPHY SERVICE, built on 2000 and last modified in 2008, for a thorough bibliographical insight into this theory and its application in linguistics, literary theory, psychology and philosophy.

3. According to Smith and Wilson (1992:5), "An utterance, on a given interpretation, is optimally relevant if and only if: (a) it achieves enough effects to be worthy of the hearer's intention; (b) it puts the hearer to no gratuitous effort in achieving those effects".

4. Explicatures are explicitly communicated assumptions -a combination of linguistically encoded and contextually inferred conceptual features- whereas implicatures are assumptions derived by inference.

5. The slightest hint of sex draws on the audience's attention, because the cognitive system of human beings is organised in such a way that is more susceptible to this kind of information than to other kinds (Tanaka, 1994 (1999: 54)). 


\section{References}

Andren, Gunnar, Lars Ericsson, Ragnar Ohlsson and Torbjörn Tännsjö (1978): Rhetoric and Ideology in Advertising (A Content Analytical Study of American Advertising). Stochholm: LiberFörlag.

Ang, Swee Hoon and Elison A. C. Lim (2006): "The influence of metaphors and product type on brand personality perceptions and attitudes". Journal of Advertising 35: 39-53.

Bhatia, Vijay K. (1992): "Discourse functions and pragmatics of mixing: advertising across cultures". World Englishes 11(2/3): 195-215.

Barcelona, Antonio, 2000: "Introduction. The cognitive theory of metaphor and metonymy". In A. Barcelona, ed., Metaphor and Metonymy at the Crossroads: A Cognitive Perspective [Topics in English Linguistics 30]. Berlin and New York: Mouton de Gruyter, 1-28.

Bencherif, S. and Keiko Tanaka (1987): "Covert forms of communication". Paper given at the Autumn Meeting of the Linguistic Association of Great Britain. Bradfort, September.

Borchers, Timothy A. (2 ${ }^{\text {nd }}$ ed.) (2002 (2005)): Persuasion in the Media Age. New York: McGraw Hill.

Caillat, Zahna and Barbara Mueller (1996): "Observations: the influence of culture on American and British advertising: an exploratory comparison of beer advertising". Journal of Advertising Research 36(3): 79-88.

Cheng, H. and John Schweitzer (1996): "Cultural values reflected in Chinese and U.S. television commercials". Journal of Advertising Research 36(3): 27-44

Cortés de los Ríos, Ma Enriqueta (2001): Nuevas perspectivas lingüisticas en la publicidad impresa anglosajona. Almería: Servicio de Publicaciones de la Universidad de Almería.

Crook, John (2004): "On covert communication in advertising”. Journal of Pragmatics 36 (4): $715-738$.

Delbecque, Nicole (1990): "El lenguaje de la publicidad y su poder de sugestión. Anuncios publicitarios en El País Semanal: Los tópicos más frecuentes y su formulación". Lingüistica española actual XII, Madrid: 197-214.

Díaz Pérez, Francisco Javier (1999): "Una aproximación al uso de la metáfora en la publicidad británica y en la española desde la teoría de la relevancia”. Pragmalingüística 7: 45-54. . (2000): "Sperber and Wilson's Relevance Theory and its applicability to advertising discourse: Evidence from British Press Advertisements". ATLANTIS XXII: 37-50.

Díez Velasco, Olga. Isabel (2001): "Metaphor, metonymy, and image-schemas: an analysis of conceptual interaction patterns". Journal of English Studies 3: 47-63.

Dirven, René, Pörings, Ralf (eds.), (2003): Metaphor and Metonymy in Comparison and Contrast. [Cognitive Linguistic Research 20]. Berlin and New York: Mouton de Gruyter.

van Enschot-van Dijk, Renske (2006): "Retoriek in reclame. Warndering voor Schema's en tropen in tekst en beeld" [Rhetoric in advertising. Appreciation of schemes and tropes in text and image]. Ph. D. Dissertation. Nijmegen: Radbound Universiteit.

Evans, Vyvyan and Melanie Green (2006): Cognitive Linguistics: A Introduction. Mahwah, NJ: Lawrence Erlbaum Associates.

Feldman, Jerome (2006): From Molecule to Metaphor. A Neural Theory of Language. Massachusetts: The MIT Press

Forceville, Charles (1994): "Pictorial metaphor in billboards: Relevance theory perspectives". In J. Müller, ed., Towards a Pragmatics of the Audiovisual, Münster: Nodus, 93-113. . (1996): Pictorial Metaphor in Advertising. London and New York: Routledge.

. (2006): "Non-verbal and multimodal metaphor in a cognitivist framework: Agendas for research". In G. Kristiansen, M. Achard, R. Dirven and F. J. Ruiz de Mendoza, eds., Cognitive Linguistics: Current Applications and Future Perspectives. Berlin: Mouton de Gruyter, 379-402. 
Fuertes-Olivera, Pedro A., Marisol Velasco-Sacristán, Ascensión Arribas-Baño and Eva SamaniegoFernández (2001): "Persuasion and advertising English: metadiscourse in slogans and headlines". Journal of Pragmatics 33(8): 1291-1307.

Geeraerts, Dirk (2003): “The interaction of metaphor and metonymy in composite expressions". In R. Dirven and R. Pörings, eds., 435-465.

Gibbs, Raymond W. Jr and Herbert J. Colston (2006): "The cognitive psychological reality of image schemas and their transformations". In D. Geeraerts, ed., Cognitive Linguistics: Basic Readings. Berlin and New York: Mouton de Gruyter, 239-268.

Gibbs, Raymond W. and Markus Tendahl (2006): "Cognitive effort and effects in metaphor comprehension: Relevance Theory and psycholinguistics". Mind \& Language 21 (3): 379-403.

Goossens, Louis (1995): "Metaphtonymy: the interaction of metaphor and metonymy in expressions for linguistic action”. In L. Goossens, P. Pauwels, B. Rudzka-Ostyn, A. M. Simon-Vanderbergen and J. Vanparys, J., eds., By Word of Mouth. Metaphor, Metonymy and Linguistic Action in a Cognitive Perspective. Amsterdam and Philadelphia, John Benjamins, 159-174.

Goatly, Andrew (1994): "Register and the redemption of relevance theory: the case of metaphor". Pragmatics 4: 139-191.

Hampe, Beate. (ed.) (2005): From Perception to Meaning. Image Schemas in Cognitive Linguistics. Berlin: Mouton de Gruyter.

Herrero Ruiz, Javier (2002): "Sequencing and integration in metaphor-metonymy interaction". RESLA 15: 73-91

Hurtienne Jörn and Johann Habauk Israel (2007): "Image schemas and their metaphorical extensions intuitive patterns of tangible interaction. Proceedings of the $1^{\text {st }}$ International Conference on Tangible and Embedded Interaction: 127-134.

Jhally, Sut (1987): The Codes of Advertising. London: Routledge.

Johnson, Mark (1987): The Body in the Mind. Chicago: University of Chicago Press. . (1993): Moral Imagination. Chicago: University of Chicago Press.

Khale, Lynn (1986): "Using the list of values (LOV) to understand consumers". Journal of Consumer Marketing 6(3):5-12.

Kneebone, John (2002): "Design et marketing, un marriage de raison?". Revue Francaise du Marketing 187, February: 93.

Kimmel, Michael (2005): "Culture regained: Situated and compound image schemas". In B. Hampe and J. E. Grady, eds., From Perception to Meaning. Image Schemas in Cognitive Linguistics. Berlin and New York: Mouton de Gruyter, 285-311.

Krzeszowski, Tomasz (1990): "The axiological aspect of idealized cognitive models", In J. Tomaszczyk and B. Lewandowska, eds., Meaning and Lexicography. Amsterdam: John Benjamins, 135-165.

. (1993): "The axiological parameter in preconceptual image schemata". In R. A. Geiger and B. Rudzka-Ostyn, eds., Conceptualizations and Mental Processing in Language. Berlin: Mouton de Gruyter, 307-330.

. (1997): Angels and Devils in Hell. Elements of Axiology in Semantics. Warsaw: Energeia. . (2004): "Metaphors of discourse: Between co-operative and oppositional discourses". In

A. Duszak, U. Okulska, eds., Speaking from the Margin. Global English from a European Perspective, Frankfurt, Peter Lang, 107-116.

Lagerwerf, Luuk (2007): "Irony and sarcasm in advertisements: Effects of relevant inappropriateness". Journal of Pragmatics 39(10): 1702-1721.

Lakoff, George (1987): Women, Fire and Dangerous Things: What Categories Reveal about the Mind. Chicago: University of Chicago Press. 
Lakoff, George and Mark Johnson (1980): Metaphors We Live By. Chicago: Chicago University Press. . (1999): Philosophy in the Flesh. The Embodied Mind and Its Challenge to Western Thought. New York: Basic Books.

Lakoff, George and Mark Turner (1989): More than Cool Reason. A Field Guide to Poetic Metaphor. Chicago: University of Chicago Press.

Lee, Michael (2008): "Persuasion in Advertising-How to use persuasion techniques in advertising". Available at $<$ http://ezinearticles.com/?Persuasion-in-Advertising---How-to-Use-PersuasionTechniques-in-Advertising\&id $=1336753>$.

Lim, Elison Ai Ching, Suree Hoon Ang, Y in Hwai Lee and Siew Leong (in press): "Processing idioms in advertising discourse: Effects of familiarity, literality, and compositionality on consumer ad response". Journal of Pragmatics (2008). doi: 10.106/j.pragma.2008.09.034.

Lukas, Scott A. (2002): “The gender ads project”. Available at $<$ http://www.genderads.com>.

Ma, Lin (2008): "Pictorial metaphor in advertising and consumer interpretation of its cultural meaning". China Media Research 4(3): 9-17.

Martin, James and David Rose (2003): Working with Discourse: Meaning Beyond the Clause. London and New York: Continuum.

McQuarrie, Edward F. Phillips and Barbara Phillips (2005): "Indirect persuasion in advertising: how consumers process metaphors presented in pictures and words". Journal of Advertising 34: 7-20.

Melchenko, Liana (2003): "Inferences in advertising: A study of Swedish and Russian TV commercials". MA Thesis: Lund University.

Meyers-Levy, Joan and Prashant Malaviya (1999): "Consumers' processing of persuasive advertisements: an integrative framework of persuasion theories". Journal of Marketing 63: 45-60.

Mills, Sara (2008): Language and Sexism. Cambridge: Cambridge University Press.

van Mulken, Margot, Renske van Enschot-van Dijk and Hans Hoeken (2005): "Puns, relevance and appreciation in advertisements". Journal of Pragmatics 37(5): 707-721.

Núñez Perucha, Begoña (2003): Esquemas de imágenes y modelos populares: un estudio del lenguaje de la victimización en textos narrativos en lengua inglesa. Logroño: AESLA (CDRom).

Panther, Klaus-Uwe (2006): "Metonymy as a usage event”. In G. Kristiansen, M. Achard, R. Dirven and F. J. Ruiz de Mendoza, eds., Cognitive Linguistics: Current Applications and Future Perspectives. Amsterdam and New York: Mouton de Gruyter: 147-186.

Panther, Klaus-Uwe and Linda L. Thornburg, (eds.) (2003): Metonymic and Pragmatic Inferencing. Amsterdam/Philadelphia: Benjamins.

Papafragou, Anna (1996): “On metonymy”. Lingua 99: 169-195.

Pateman, Trevor (1983): "How is understanding an advertisement possible?". In H. Davis and P. Walton, eds. Language, Image, Media. Oxford: Blackwell, 187-204.

Pauwels, Paul and Anne-Marie Simon-Vandenbergen (1993): "Value judgment in the Metaphorization of linguistic action". In R. A. Geiger and B. Rudzka-Ostyn, eds., Conceptualizations and Mental Processing in Language. Berlin: Mouton de Gruyter, 331-367.

. (1995): "Body parts in linguistic action: underlying schemata and value judgments". In L. Goossens, P. Pauwels, B. Rudzka-Ostyn, A. Simon-Vandenbergen and J. Vanparys, eds., By Word of Mouth: Metaphor, Metonymy and Linguistic Action in a Cognitive Perspective. Amsterdam: John Benjamins, 35-70.

Peña, Sandra (2000): A Cognitive Approach to Image-Schematic Component in the Metaphorical Expression of Emotion in English. Logroño: Universidad de la Rioja.

Pollay, Richard. W. (1984): "The identification and distribution of values manifest in print 
advertising", 1900-1980. In R. E. Pitts and A. G. Woodside, eds., Personal Values and Consumer Psychology. Lexinton, MS: Lexinton Press, 11-129.

Pop, Anişoara (2008): The Grammar of Advertising. Cluj-Napoca: Editura Risoprint.

Radden, Günter and Zoltan Kövecses (1999): "Towards a theory of metonymy". In Klaus-Uwe Panther and Günter Radden, eds., Metonymy in Language and Thought. Amsterdam/Philadelphia: Benjamins.

Riemer, Nick (2001): "Remetonymizing metaphor: Hypercategories in a semantic extension". Cognitive Linguistics 12: 379-401.

Rocamora Abellán, Rafael (2004): "Metonymy-based metaphors in advertising". Linguagem, cultura e cogniçao. Estudos de Lingüística Cognitiva 2: 245-261.

Roiz Célix, Miguel (1996): Técnicas modernas de persuasión. Madrid: Biblioteca Eudema.

Ruiz de Mendoza Ibáñez, Francisco José (1997a): “Metaphor, metonymy and conceptual interaction”. ATLANTIS 19(1): 201-295.

. (1997b): "Cognitive and pragmatic aspects of metonymy". In A. Barcelona, ed., Cognitive linguistics in the study of the English language and literature in English. Monograph issue of Cuadernos de Filología Inglesa 6(2):161-178.

. (1998): "Understanding through metonymy: the role of metonymy in communication and cognition”. In B. Peñas, ed., The Pragmatics of Understanding and Misunderstanding, Zaragoza: Universidad de Zaragoza, Servicio de Publicaciones, 197-208.

. (1999a): "Introducción a la Teoría Cognitiva de la Metonimia". Granada: Método.

. (1999b): "From semantic underdetermination via metaphor and metonymy to conceptual interaction". Laud 492: 1-21.

. (2000): "The role of mappings and domains in understanding metonymy". In A. Barcelona, ed., Metaphor and Metonymy at the Crossroads: A Cognitive Perspective. [Topics in English Literature 30]. Berlin and New York: Mouton de Gruyter, 109-132.

Ruiz de Mendoza Ibáñez, Francisco José and Olga Isabel Díez Velasco (2003): "Patterns of conceptual interaction”. In: Dirven, R., Pörings, R. eds., 489-532.

del Sáez Rubio, $M^{\mathrm{a}}$ Milagros and Barry Pennock Speck (2008): "An approach to the notion of covert/overt communication in television commercials". Paper presented at the XXVII International Conference of AESLA- Asociación Española de Lingüística, held in Ciudad Real on 26-28 March 2009.

Schmidt, Rosmarie and Joseph F. Kess (1986): Television Advertising and Televangelism: Discourse Analysis of Persuasive Language. Amsterdam and Philadelphia: John Benjamins.

Sinha, Christopher (2002): "The cost of renovating the property: a reply to Marina Rakova". Cognitive Linguistics 13: 271-276.

Smith, Neil and Deirdre Wilson (1992): "Introduction". Lingua 87: 1-10.

Sperber, Dan and Deirdre Wilson ( $2^{\text {nd }}$ ed.) (1986 (1995)): Relevance: Communication and Cognition. Oxford UK and Cambridge USA: Blackwell.

. (2002): "Pragmatics, modularity and mind-reading". Mind and Language 17: 3-23.

. (2008): “A deflationary theory of metaphor". In R. Gibbs, ed., Cambridge Handbook of Metaphor and Thought. New York: Cambridge University Press, 84-105.

Talmy, Leonard (1988): "Force dynamics in language and cognition". Cognitive Science 12:49-100.

Tanaka, Keiko (1992): “The pun in advertising: A pragmatic approach". Lingua 87: 91-102. . ( $2^{\text {nd }}$ ed.) (1994 (1999)): Advertising Language: A Pragmatic Approach to Advertisements in Britain and Japan: London: Routledge.

Taylor, John R. (1995): Linguistic Crosscategorisation. Prototypes in Linguistic Theory. Oxford: Clarendon Paperbacks. 
Umiker-Sebeok, Jean (1996). "Power and the construction of gendered spaces". International Review of Sociology 6(3): 389-403.

Ungerer, Friedrich (2000). "Muted metaphors and the activation of metonimies in advertising". In A. Barcelona, ed., Metaphor and Metonymy at the Crossroads. A Cognitive Perspective. Berlin and New York: Mouton de Gruyter, 321-340.

Velasco Sacristán, Marisol (in press, a): "Overtness-covertness in advertising gender metaphors". Journal of English Studies.

. (in press, b). "Interacción entre metáfora y metonimia en el discurso publicitario". RESLA (paper presented at the XXVII International Conference of AESLA- Asociación Española de Lingüística, held in Ciudad Real on 26-28 March 2009).

Velasco Sacristán, Marisol y Pedro A. Fuertes-Olivera (2004). "Metáfora y LSP: Valor cognitivo de la metáfora en el discurso publicitario de British Cosmopolitan". In I. Sanz Sainz and A. Felices Lago, eds., Las nuevas tendencias de las lenguas de especialidad en un contexto internacional y multicultural. Granada: Universidad de Granada, 863-878.

. (2006): "Towards a critical cognitive-pragmatic approach to gender metaphors in Advertising English". Journal of Pragmatics 38(11): 1982-2002.

Wilson, Deirdre and Dan Sperber (2004): "Relevance theory". In L. R. Horn and G. Ward, eds., Handbook of Pragmatics. Section 3. Oxford: Blackwell, 607-632.

Wilson, Deirdre and Robyn Carston (2006): "Metaphor, relevance and the 'emergent property' issue". Mind \& Language 21: 406-433.

Yus Ramos, Francisco (1998): “A decade of relevance theory”. Journal of Pragmatics 30: 305-345. . (2000-2010): Relevance theory bibliographic service (Thematic sections). Created in 2000 and last modified on 28 November 2008. URL:

$<$ http://www.ua/personal/francisco.yus/rt.htm>

Zargaj-Reynolds, Paula (2008-2009): “The Advertising is Good for You" blog" (especially its section on 'Sexist advertising'). Available at

$<$ http://pzrservices.typepad.com/advertisingisgoodforyou/sexist_advertising $>$.

Zlatev, Jordan (2005): "What's in a schema? Bodily mimesis and the grounding of language". In B. Hampe and J. E. Grady, eds., From Perspection to Meaning. Image Schemas in Cognitive Linguistics. Berlin and New York: Mouton de Gruyter, 313-342. 